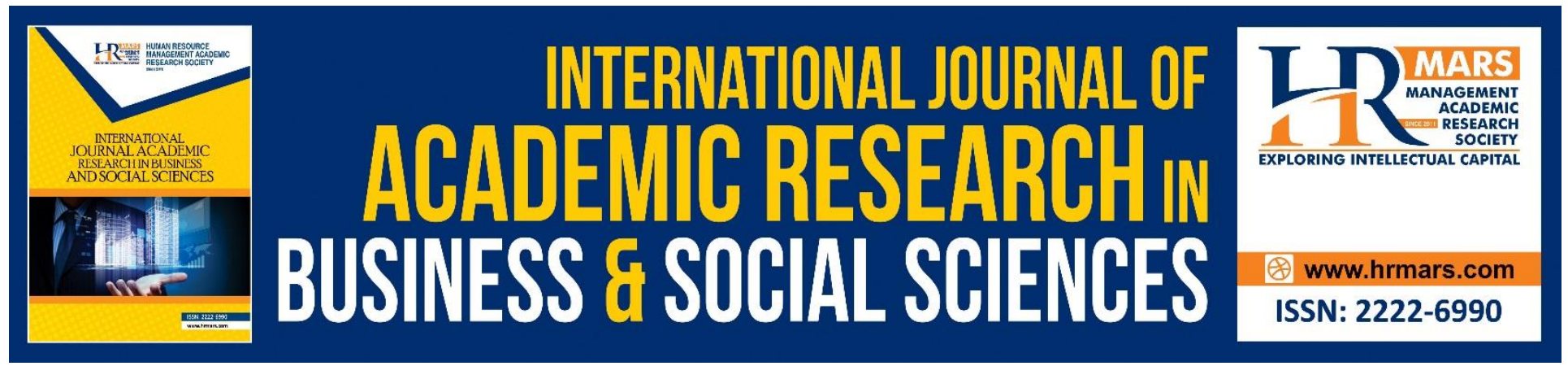

\title{
The Effect of Asset Structure, Profitability, Company Growth, and Dividend Policy on Financial Leverage (A Study in Lq 45 Companies Listed In Indonesia Stock Exchange in 2012- 2016)
}

Winni Rizki Putri, Yossi Diantimala, Mulia Saputra

To Link this Article: http://dx.doi.org/10.6007/IJARBSS/v9-i6/5946

DOI: $10.6007 /$ IJARBSS/v9-i6/5946

Received: 10 April 2019, Revised: 20 May 2019, Accepted: 01 June 2019

Published Online: 15 June 2019

In-Text Citation:(Putri, Diantimala, \& Saputra, 2019)

To Cite this Article: Putri, W. R., Diantimala, Y., \& Saputra, M. (2019). The Effect of Asset Structure, Profitability, Company Growth, and Dividend Policy on Financial Leverage (A Study in Lq 45 Companies Listed In Indonesia Stock Exchange in 2012-2016). International Journal of Academic Research in Business and Social Sciences, 9(6), 271-227.

Copyright: (C) 2019 The Author(s)

Published by Human Resource Management Academic Research Society (www.hrmars.com)

This article is published under the Creative Commons Attribution (CC BY 4.0) license. Anyone may reproduce, distribute, translate and create derivative works of this article (for both commercial and non-commercial purposes), subject to full attribution to the original publication and authors. The full terms of this license may be seen at: http://creativecommons.org/licences/by/4.0/legalcode

Vol. 9, No. 6, 2019, Pg. 271 - 284

Full Terms \& Conditions of access and use can be found at http://hrmars.com/index.php/pages/detail/publication-ethics 


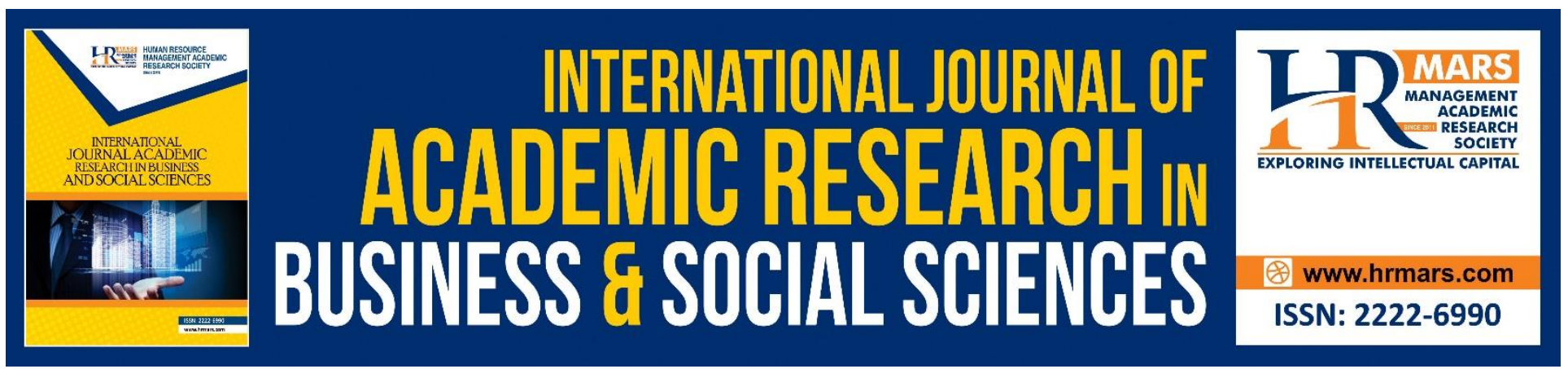

\title{
The Effect of Asset Structure, Profitability, Company Growth, and Dividend Policy on Financial Leverage (A Study in Lq 45 Companies Listed In Indonesia Stock Exchange in 2012-2016)
}

\author{
Winni Rizki Putri, Yossi Diantimala, Mulia Saputra \\ Accounting Department, Faculty of Economics and Business, Syiah KualaUniversity, Banda Aceh, \\ Indonesia
}

\section{Abstract}

This study aimed to examine the effect of asset structure, profitability, company growth, and dividend policy on financial leverage in LQ 45 companies listed in Indonesia Stock Exchange in 20122016. This research used secondary data from the company's financial statements. The data were collected by using purposive sampling technique with a total sample of 82 companies. The analysis method used was the analysis of panel data regression. The result showed that partially asset structure, profitability, and company growth significantly influence the financial leverage in LQ 45 companies listed in Indonesia Stock Exchange in 2012-2016. The dividend policy did not significantly influence the leverage financial in LQ 45 companies listed in Indonesia Stock Exchange in 2012-2016.

Keywords: Financial Leverage, Asset Structure, Profitability, Company Growth, And Dividend Policy.

\section{Introduction}

Brigham and Houston (2011) stated that the capital market is the evidence of the advancement of more modern sciences and technologies in the economic field becomes an appropriate and effective means for the investor to invest in profitable areas. In addition, in the effort to obtain the capital for companies, the capital market is the right means. The need for this fund involved a funding policy. The interested party, in this case, is the financial manager which asked to find and evaluate the funding sources that were useful for the survival of the company (Gitosudarmo \& Basri, 2000).

Basically, the shareholders want that the investment fund is safe so they will get profits from the investment, while the managerial parties want the compensation on their effort in running the company in the form of salary and other incentives. One of the alternatives that can be done by the manager to get fund in the context of expansion is through debt. However, the manager tends to 
dislike it, arguing that the debt has a high risk even though the rate of return on debt costs is high (Jensen dan Meckling,1976). This matter will emerge the agency conflict between shareholders and creditor. Therefore, it is very necessary to have a mechanism which can align both parties. Unfortunately, this will cause the new cost form which called agency cost (Jensen dan Meckling, 1976).

Riyanto (2011)said that a company in its activities definitely need a lot of funds in its operational activities. A company funding usually sourced from the internal fund where the funds are sourced from company activities such as running profits, retained earnings, and share capitals which related to the dividend policy. The external fund is funds that source from external, such as the use of longterm debt which related to to the company's debt policy.

The impacts of the use of debt on the company are, first, if the company uses the capital sourced from equity, then negative signals will arise among investors which lead to asymmetric information. Second, creditors can see equity as a barrier. The use of debt is not always good. Sometimes, the company uses equity to pay off the debt if the company is unable to pay it. Third, the company will have the interest debt through the debt which causes a reduction of the amount of tax paid so that will increase the earnings per share (EPS) for shareholders (Brigham \& Houston, 2011:140).

Leverage represents the use of debt in the company capital structure. When a company takes a loan, it will increase its financial leverage and the risk also will increase. Financial leverage will decrease by new investment and the risk also will reduce. Hence, every change in financial leverage can lead to the potential to get a positive or negative result from every taken policy. In this case, the manager has to equalize between the debt and the shareholders right (Zare et.al, 2013)

Financial Leverage shows how far the company assets have been funding through the use of debt (Kasmir, 2011: 151). According to Hanafi (2004:332), financial leverage is the amount of interest debt that must be regularly issued by the company as a result of the use of debt. If the company does not have enough fund or capital, then the company tends to use the debt. The more the debt used by the company, the higher the risk that will face by the investors, yet, the profits that expected by investors will also increase. In other hands, the other reason why the company prefers to use a fund with a fixed debt because it is expected the income that available to shareholders will increase. Thus, financial leverage shows the changes in earnings per share (EPS) as a result of changes in EBIT.

The increasing of the use of financial leverage will result in high fixed capital cost leading the company must increase the additional EBIT rather than its fixed cost. If a company used high financial leverage, then it will raise the financial risk (Horne dan Wachowicz, 2013). In this research, financial leverage is proxied with Debt to Equity Ratio where DER is total debt ratio on total equity. The use of optimal financial leverage is how the company able to manage the debt with its own capital. This is reflected from DER value which if the ratio increase, then it will show bad things for the company (Sartono, 2010:66). Table 1.1 shows the values of DER and EPS from several companies LQ 45 registered in Indonesia Stock Exchange in 2012-2016. 
INTERNATIONAL JOURNAL OF ACADEMIC RESEARCH IN BUSINESS AND SOCIAL SCIENCES

Vol. 9, No. 6, June, 2019, E-ISSN: 2222-6990 (C) 2019 HRMARS

Table 1.1

DER and EPS Period $2012-2016$

\begin{tabular}{|c|c|c|c|c|c|c|c|c|c|c|c|}
\hline \multirow[t]{2}{*}{ No } & \multirow{2}{*}{$\begin{array}{l}\text { Comp } \\
\text { anies } \\
\text { Name }\end{array}$} & \multicolumn{5}{|c|}{ Debt to Equity Ratio (\%) } & \multicolumn{5}{|c|}{ EPS (Earning per Share) (Rp) } \\
\hline & & 2012 & 2013 & 2014 & 2015 & 2016 & 2012 & 2013 & 2014 & 2015 & 2016 \\
\hline 1 & $\begin{array}{l}\text { PT. } \\
\text { AKR } \\
\text { Corpo } \\
\text { rindo, } \\
\text { Tbk. }\end{array}$ & 1,80 & 1,73 & 1,48 & 1,09 & 0,96 & 168,5 & 167,4 & 206,9 & 262,3 & 253,2 \\
\hline 2 & $\begin{array}{l}\text { PT. } \\
\text { Bank } \\
\text { Centr } \\
\text { al } \\
\text { Asia, } \\
\text { Tbk. }\end{array}$ & 7,52 & 6,76 & 6,06 & 5,60 & 4,97 & 475,4 & 578,1 & 668,6 & 730,8 & 835,7 \\
\hline 3 & $\begin{array}{l}\text { PT. } \\
\text { Media } \\
\text { Nusan } \\
\text { tara } \\
\text { Citra, } \\
\text { Tbk. }\end{array}$ & 0,23 & 0,24 & 0,45 & 0,51 & 0,50 & 118,7 & 119,9 & 123,4 & 83,05 & 95,87 \\
\hline 4 & $\begin{array}{l}\text { PT. } \\
\text { Bukit } \\
\text { Asam, } \\
\text { Tbk. }\end{array}$ & 0,50 & 0,55 & 0,71 & 0,82 & 0,76 & 1258 & 792,5 & 875,0 & 883,5 & 870,6 \\
\hline 5 & $\begin{array}{l}\text { PT.Gu } \\
\text { dangG } \\
\text { aram, } \\
\text { Tbk. }\end{array}$ & 0,56 & 0,73 & 0,75 & 0,67 & 0,59 & 2086 & 2249 & 2790 & 3344 & 3470 \\
\hline
\end{tabular}

Source: The Processed Data, 2018

The changing DER value indicated the use of debt by the company. If the company used high debt, it will be reflected by its DER value. This is will increase the risk borne by the company. Fahmi (2013) asserted that if the DER value is above $1(1.00)$, it means that a company used more debt than its own capital. In the capital structure theory, it is not allowed that the debt more than its own capital, if DER value is above $1(1.00)$ it means there is an increase in the company's risk. However, according to the table 1.1, the DER value is varied, the company with DER value above 1 still can survive in the LQ 45 index even though the higher the ratio, the more companies' activities funded by the debt and also have a high risk. The use of debt will cause a risk that is when the company has a debt higher than asset value which guarantees the debt. 
Fahmi (2013) also stated that through the use of financial leverage shows how the use of the funds able to give additional profits for the company so that the shareholders' profit or earnings per share increase which reflected from the value of Earning per Share (EPS). It is not always when the higher the debt, the more the profit. The EPS value is a benchmark for achieving good financial performance, especially in the utilization of capital or the company's asset. The number of EPS value is influenced by factors of capital structure and the level of net income before taxes and interest. Both factors at the same time emphasize the funding sources alternative through debt or financial advantage (Maimunah \& Rahajeng, 2015).

In determining the capital structure by the company is closely related to the funding decision. All errors in the decision-making process can affect decreasing the company's value leading to decreasing shareholders prosperity. Therefore, the company needs to analyze some factors that can influence the funding decision (Erkaningrum, 2008). The first factor that suspected in influencing financial advantage is asset structure. A study on the effect of asset structure on financial leverage conducted by Erkaningrum (2008) and Zare et al., (2013) showed that asset structure has a positive effect on financial leverage. This is because the company can use the number of its assets as collateral for the loans made (Brigham \& Houston, 2011:188).

Besides, the factor that influences the financial leverage is profitability. Profitability is the ability of a company to operate in the long-term depending on the acquisition of an adequate level of profit (Pearce \& Robinson, 2008:251). The result of the research by Erkaningrum (2008), Destriana, Nicken \& Yeniatie (2010). Siregar \& Wiksuana (2015) indicated that profitability has a negative effect on financial leverage. This is because the company has a high rate of return on the investment so that the use of debt is relatively small which enable the company to use internal cost in financing its activities. The company tends to use the retained earnings before deciding to use the external funds which are the debt.

Company growth is also suspected in influencing financial leverage. According to the study result by Siregar \& Wiksuana (2015), Gill, A. \& Neil (2011), Putra, Dedi \& Lilik (2017), the company growth has a positive effect on financial leverage. Brigham and Houston (2011) pointed out that the tendency of a company to use external funds, which is the debt, is greater when that company has the high level of sales and profits compared to the company with low sales level. The company growth level can indicate how much the debt used by the company as the funding source. The higher the company growth, the more the company tends to use the debt in financing the company's funding needs.

The last factor that influences the financial leverage is dividend policy, where dividend distribution will decrease the company's debt level (Murni \& Andriana, 2007). Erkaningrum, Indri (2008), Putra, Dedi \& Lilik (2017) found that the dividend policy has a negative effect on financial leverage. The company with high dividend payout ratio tends to like internal funding that is its own capital since the company obligation will increase and generally the dividend payments can be done after the payments of interest and debt repayment so that the manager will be more careful and efficient in using the debt (Fidyati, 2003).

This study also included several variables as control variable such as the size of the company (Erkaningrum, 2008; Gill \& Neil, 2011), managerial ownership (Wahidahwati, 2002), and institutional ownership (Wahidahwati, 2002; Putra,\& Lilik, 2017). Many previous studies had conducted a study on financial leverage which illustrated how far a company used the debt as its funding source. The 
object used in this research was LQ 45 companies listed in Indonesia Stock Exchange in 2012-2016. Based on the explanation above, the researcher interested to conduct a study under the title "The Effect of Asset Structure, Profitability. Company Growth, and Dividend Policy on Financial Leverage (A study at LQ 45 companies listed in Indonesia Stock Exchange in 2012-2016)".

\section{Literature Review}

Agency Theory

According to Jensen and Meckling (1976), agency theory is the agency relationship that arises between agent and principal which bound in a contract where an agent acts as vise principal in making a decision for a company. Meanwhile, according to Brigham \& Houston (2000) agency theory is the provision of power from shareholder to the manager in the decision-making related to the company in order to achieve the company goals such as maximizing the shareholder's welfare. However, in the practice, there is different interest between manager and shareholders which cause the potential conflict on the interest.

According to Weston and Copeland $(1992 ; 20)$, it is difficult to trust the management (agent) because they always will act based on the shareholder interest (principal). Therefore, it is needed a mechanism such as monitoring and controlling to minimize the agency conflict, for example, managerial ownership, dividend policy, and debt policy (Jensen \& Meckling, 1976).

\section{The Pecking Order Theory}

According to Myers (1984), pecking order theory has a basic thought that debt to equity ratio is not targeted to a certain level, but it only has the order of funding sources in which most preferred by the company. In the pecking order theory, there is a sequence in funding decision started from internal funding such as debt to the issuance of new equity. This indicates that the funding starts from the cheaper funding sources (Myers and Majluf, 1984).

\section{Financial Leverage}

Financial Leverage is the use of fund which has fixed debit with a hope that it will provide the additional profit greater than its fixed debt so the profits available for shareholders will increase (Sartono,2010:263). Furthermore, Brigham and Houston (2011:440) explained that financial leverage is a measure of how much the securities and profits or fixed returns such as debt and preferred shares used in the capital structure. Van Horne et al. (2013) divide the leverage ratio into two; debt ratio and debt to equity ratio.

\section{Asset Structure}

Riyanto (2011) defined that wealth structure is a balance between current asset and fixed asset. According to Husnan and Pudjiastuti (2015), the investment decision reflected in the side of a company is a comparison between current asset and fixed asset which influence the company wealth structure. Therefore, it can be concluded that what is meant by asset structure is the description of the proportion or the comparison between a total fixed asset owned by the company and a total company asset. 


\section{Profitability}

Profitability is the ability of a company to obtain a profit in a certain period (Kasmir, 2011:196). Husnan (2005) defined that profitability is the ability of a company to generate profits at the level of sales, assets, and certain share capital. In addition, according to Sartono (2010), profitability is the ability of a company in acquiring the profits related to sales, total assets, and its own capital. In this research, the profitability was measured by ROA (Return On Assets) ratio by comparing the profits after tax with total assets.

\section{The Company Growth}

The company growth can be defined as the development of sales, profits, or assets (Halim dan Sarwoko, 1995:7). The company growth can be measured by looking at the sales level. The sales have a strategic influence on a company. Hence, the sale should be supported by the wealth or asset and if the sale is increased, then the asset should be added (Weston and Brigham, 1991:95).

\section{The Dividend Policy}

According to Martono and Harjito (2008), dividend policy is the decision is related to whether the profits obtained by the company will be divided to shareholders in the form of a dividend or will be used as retained earnings in order to increase the investment financing capital in the future. Husnan (2005) argued that dividend policy is the use of company profits whether the profits will be retained as retained earning or will be divided to shareholders. This dividend policy used the dividend payout ratio (DPR) as the formula where DPR shows the percentage of the profits paid in cash to shareholders (Wahidahwati, 2002).

\section{The Effect of Asset Structure on Financial Leverage}

The asset structure is closely related to corporate wealth. Companies with a more flexible asset structure will use more debt when compared to companies whose asset structure is not flexible because these assets can be used as collateral in making loans. Investors will always provide loans to companies whose assets are suitable for credit guarantees (Brigham and Houston 2001: 39-41). The high level of fixed assets owned by a company will result in increased funding through debt. This is because the creditor is more convinced that the company is able to pay the debt. Erkaningrum, I. (2008) examined the determinants of financial leverage in the capital structure. The result is the asset structure has a significant positive influence on financial leverage. Zare et al., (2013) also explained the structure of company assets that have a positive influence on financial leverage.

\section{The Effect of Profitability on Financial Leverage}

Profitability can be used as one of the indicators used by creditors as a reference in making decisions. Myers (1984) says that if retained earnings are owned by a large company, the company will reduce borrowing from outside the company. The use of retained earnings will take precedence before deciding to use debt. If the company has a high return on investment, the company uses internal funds first in financing its activities. That's because companies with large profits will allocate it to retained earnings so that internal funding is more reliable than using debt. This is consistent with the 
research of Siregar \& Wiksuana (2015) and Erkaningrum, I (2008) which say that profitability has a negative influence on financial leverage.

The Effect of Company Growth on Financial Leverage

To see the prospects of the company in the future, it can use the company's growth rate (growth) (Murni and Adriana, 2007). Where high growth shows the company has the resources to generate good growth and profits. The stable level of sales of a company will make it easier for the company to obtain debt, and if the company's level of sales is unstable, it will bear a higher fixed burden. This means that companies with high sales levels will be safer when using debt (Brigham \& Houston, 2011: 39). Although the use of corporate risk debt increases, investors believe that management will be able to manage debt as efficient as possible so that it does not have a negative effect on the company. Siregar \& Wiksuana Research (2015) show that company growth has a positive influence on financial leverage. Similarly, Putra.D \& Lilik (2017) found that the company's growth also had a positive influence on debt policy.

The Effect of Dividend Policy on Financial Leverage

According to Rozeff (1982) dividend payment is a form of monitoring carried out by the principal towards the management as an agent. Larasati (2011) says dividend payments can be used to reduce agency costs. Companies with high dividend payout ratios tend to use their own capital to reduce agency costs. Through dividend payments, the company's obligation to pay dividends will increase, but the payment can be made after payment of interest and debt repayments have been fulfilled. This is what makes the manager as an agent more careful and efficient in using debt. Wibowo \& Erkaningrum (2002) said that dividend policy has a negative effect on financial leverage. The same thing was found by Erkaningrum, I who said dividend payout ratio had a negative influence on financial leverage. Based on the framework and previous research, the following hypotheses were obtained:

H1: Asset structure has the effects of financial leverage

H2: Profitability has an effect of financial leverage

H3: Company growth has an effect on financial leverage

$\mathrm{H} 4$ : Dividend policy has an affects financial leverage

\section{Research Methodology}

The purpose of this study is to test the hypothesis (testing hypothesis research) in seeing the influence of independent variables (asset structure, profitability, company growth, and dividend policy) on the dependent variable (financial leverage). Control variables such as company size, managerial ownership, and institutional ownership were also used in this study. The population used is LQ 45 companies listed on the Indonesia Stock Exchange. The study population period includes data from 2012 - 2016. This study used a purposive sampling method in order to get a representative sample based on predetermined criteria. The criteria are (1) IQ 45 companies listed on the Indonesia Stock Exchange during 2012-2016. (2) Lq 45 companies that distribute dividends during the study period from 2012-2016. (3) 45 companies have managerial ownership. (4) Companies that have 45 institutional ownership. (5) Company number 45 has complete research variable data. 
Financial leverage uses the measurement of debt to equity ratio, asset structure measured by current assets divided by fixed assets, profitability using return on assets, company growth using current sales data minus sales then divided by past sales, dividend policy measured by dividend payout ratio. However, company size uses the logarithm of total assets, managerial ownership using the number of managerial share ownership divided by total shares and institutional ownership proxied by the number of institutional shares divided by total shares. The analytical method is panel data regression analysis before the classical assumption test is carried out.

\section{RESEARCH RESULT AND DISCUSSION}

Description of Research Data

In this study, the unit of analysis is the 45 LQ company listed on the Indonesia Stock Exchange with its financial statements as an observation unit during 2012-2016. The population is 225 companies with 45 IQs. After purposive sampling, the samples obtained are 82 company financial statements 45 LQ, 2012-2016.

\section{Discussion}

\section{The Effect of Asset Structure on Financial Leverage}

Hypothesis testing results show the first hypothesis $(\mathrm{H} 1)$ is accepted, which means the asset structure has a negative influence on financial leverage. From the results obtained from this test, it can be seen that the greater the proportion of fixed assets of the company, the lower the level of financial leverage of the company. Brigham and Houston (2011) say that a flexible asset structure is closely related to corporate wealth that can be used as collateral to obtain debt. This makes investors always give loans if they have collateral. This does not apply in this study because companies with large asset structures tend to reduce their level of leverage. This is in line with the research conducted by Munawar (2009) and Sarda (2009) who found that asset structure has a negative influence on capital structure. It appears that LQ 45 companies tend to like using internal funds to finance their operations. In line with the pecking order theory, where the use of internal funding sources, the risks that may arise from making new debt policy will decrease. If the company has a large asset structure and uses debt, the company will have a large burden and risk for the company (Cristine, 2010).

\section{The Effect of Profitability on Financial Leverage}

The results of hypothesis testing show that the second hypothesis $(\mathrm{H} 2)$ is accepted, it means that profitability has a negative influence on financial leverage. Companies with high DER tend to have low ROA and vice versa (Harahap, 2010: 303). DER itself shows the extent to which debts to external parties can be covered by the owner's capital. This is in line with the study of Ezeoha (2008), Siregar \& Wiksuana (2015), Erkaningrum, I (2008), Nawaz et, al (2015) who found that profitability had a negative effect on financial leverage. According to Sartono (2010), high profitability allows companies to withstand greater profits. If the retained earnings are large, the company will use these funds before choosing to use debt. The level of profitability can be used as a guide to see the ability of a company to fund its own operational activities. A high level of profitability also indicates that the company has substantial internal funds that tend to reduce the debt level. 


\section{The Effect of Company Growth on Financial Leverage}

From the results of hypothesis testing, it can be seen that the third hypothesis (H3) is accepted, it means that the growth of the company has a positive influence on financial leverage. This result is in line with the research of Yeniatie and Destriana (2010), and Siregar \& Wiksuana (2015) which said that the growth of companies has a significant positive effect on financial leverage. Sujoko and Soebiantoro (2007) say that in considering debt decisions, one must look at sales growth variables. The higher the growth rate of a company, the more it tends to require more funds from external funding sources. Relatively stable sales will tend to make it easier for companies to obtain external funds or debt flows. According to Brigham \& Houston (2011: 189) company growth can be known through sales growth where if the growth of high companies indicates that the company has bright prospects because the level of sales that are relatively stable and tend to increase, will show the company's ability to pay off its debt.

\section{The Effect of Dividend Policy on Financial Leverage}

The results of hypothesis testing indicate that the fourth hypothesis $(\mathrm{H} 4)$ is not accepted, which means that the dividend policy does not have an effect on financial leverage. The research of Yeniatie and Destriana (2010), and Akbar and Ruzikna (2017) also found that dividend policy has no influence on debt policy. If the company's dividend payout ratio is low, the company will prefer funding with its own capital because if they use a large amount of debt, the company's leverage will be higher. The effect of the dividend policy on financial leverage in LQ 45 companies is because the mechanism used in dividend payments does not work effectively even though the mechanism is used to monitor agency problems in lieu of debt. This means that the company must be careful in making decisions for additional debt because the addition of debt will increase the company's debt burden and the funds needed are even greater to pay off the debt.

\section{The Effect of Company Size on Financial Leverage}

From the hypothesis testing that has been done, the results show that the fifth hypothesis (H5) is accepted, meaning that the size of the company has a positive influence on financial leverage. The results of this study are consistent with the research conducted by Titman and Wesels (1988), Crutchley and Hansen (1989), Padron et al. (2005), Erkaningrum, I (2008) who found that company size has a positive influence on leverage. The size of the company has an important influence in the company, where large companies are considered to have the ability to access the capital market easily so that the company has flexibility in terms of obtaining funds (Diantimala, 2008). This applies in this study where LQ 45 companies have relatively large total assets so that they have the ease of obtaining the needed external funds. Creditors will prefer to give credit to large companies because they are considered to have small opportunities in terms of bankruptcy and inability to pay off debts compared to small companies. The same is true for investors who prefer large companies because they are considered to have good development so that they are more confident that later they will obtain a favorable rate of return (Sari et al, 2013). 


\section{The Effect of Managerial Ownership on Financial Leverage}

The results of hypothesis testing indicate that the sixth hypothesis ( $\mathrm{H} 6$ ) is not accepted, meaning that managerial ownership has no influence on financial leverage. This is because the proportion of managerial ownership still tends to be very low. It can be seen that the company's managerial ownership during the year of observation averaged under $5 \%$. With the low management of obtaining shares resulting in less influential managers in the General Meeting of Shareholders (GMS). This is in line with the research of Djabid (2007), Nurhayati (2004), and Purwasih, et al. (2014). It is seen that the number of managerial share ownership is still very small when compared to other groups within the company, which results in the benefits of ownership not being felt by the manager. This is why managers cannot make decisions based on their own desires (Yeniatie and Nicken, 2010).

\section{The Effect of Institutional Ownership on Financial Leverage}

Hypothesis testing shows the result of the seventh hypothesis (H7) is not accepted, which means managerial ownership has no influence on financial leverage. The non-influence of institutional ownership on financial leverage is caused by some investors not taking into account where to get sources of funds for companies, including through debt. Institutional investors will be more interested in paying attention to good corporate performance reflected in company profits. This results in even though the institutional ownership of the company by large institutions will not cause the supervision system to be more effective (Bodie, 2006). This is in line with the research of Djabid (2007) and Susanto (2011) where institutional ownership has no influence on debt policy.

\section{Conclusion and Suggestion}

The conclusion of the testing and analysis of data in this study are:

1. Asset structure affects financial leverage in LQ 45 companies listed on the Indonesia Stock Exchange in 2012-2016

2. Profitability affects financial leverage in LQ 45 companies listed on the Indonesia Stock Exchange in 2012-2016

3. The company growth affects the financial leverage of LQ 45 companies listed on the Indonesia Stock Exchange in 2012-2016

4. Dividend policy does not affect the financial leverage of LQ 45 companies listed on the Indonesia Stock Exchange in 2012-2016

5. Company size affects financial leverage in LQ 45 companies listed on the Indonesia Stock Exchange in 2012-2016. Managerial ownership does not affect the financial leverage of LQ 45 companies listed on the Indonesia Stock Exchange in 2012-2016. Institutional ownership does not affect the financial leverage of LQ 45 companies listed on the Indonesia Stock Exchange in 2012-2016.

Some limitations that limit the perfection of this research are:

1. This study uses a purposive sampling method in which the company used is a company that has predetermined provisions regarding certain criteria. So that the results obtained cannot be generalized to all companies listed on the IDX in 2012-2016. 
2. The research observation period used was only five years so that the number of companies that became research samples was smaller.

3. With the limited number of companies that have managerial and institutional ownership variables as well as the same company, the number of samples obtained is also less than previous research.

Suggestions intended for investors, \& companies and academics, namely:

Operational suggestions:

1. Investors, through this research, can consider all the factors that affect the level of financial leverage of the company, whether in the decision-making process such as investment, credit or other similar decisions so that they can be more careful and on target to improve the welfare of holders stock.

2. For companies, it is expected to be used as a material for consideration in terms of funding decisions so as to reduce agency problems.

Theoretical developmental suggestions:

1. Expand the unit of research analysis, not only limited to LQ 45 companies, so that the results of their research can be generalized for all types of companies.

2. The time span in further research should be longer so that the samples obtained are more extensive, and the results obtained are also wider.

\section{Acknowledgments}

Thanks to my supervisors, Mrs. Yossi Diantimala and Mr. Mulia Saputra for all their guidance.

\section{References}

Akbar, Deni \& Ruzikna. (2017). Pengaruh Struktur Kepemilikan, Free Cash Flow, Struktur Aset, dan Kebijakan Dividen terhadap Kebijakan Hutang Pada Perusahaan Sub Sektor Otomotif dan Komponen Yang Terdaftar di Bursa Efek Indonesia. Jurnal Online Mahasiswa. Vol.4 No.2 Oktober 2017.

Bodie, K. M. (2006). Investasi. Jakarta: Salemba Empat.

Brigham, E.F. \& Houston, J.F. (2011). Dasar-Dasar Manajemen Keuangan. Edisi ke 11. Penerjemah Ali Akbar Yulianto. Jakarta: Salemba Empat.

Crutchley, C.E \& Robert, S.H. (1989). A Test of the Agency Theory of Managerial Ownership, Corporate Leverage, and Corporate Dividend. Financial Management (Winter), 36-46.

Erkaningrum, F.I. (2008). Faktor-Faktor Penentu Financial Leverage dalam Struktur Modal. Jurnal Bisnis dan Akuntansi Analisis, 1 (2), 64-85.

Ezeoha, A.E. (2008). Firm Size and Corporate Financial Leverage Choice in a Developing Economy: Evidence From Nigeria. The Journal of Risk Finance. Vol.9, No.4, 351-364.

Diantimala, Y. (2008). Pengaruh Akuntansi Konservatif, Ukuran Perusahaan, dan Default Risk Terhadap Koefisien Respon Laba (ERC). Jurnal Telaah \& Riset Akuntansi. Vol. 1 No. 1 Januari 2008. 102-122.

Djabid, A. W. (2009). Kebijakan Dividend and Struktur Kepemilikan Terhadap Kebijakan Utang: Sebuah Perspektif Agency Theory. Jurnal Keuangan dan Perbankan. Vol.13, No.2, 249-259. 
INTERNATIONAL JOURNAL OF ACADEMIC RESEARCH IN BUSINESS AND SOCIAL SCIENCES

Vol. 9, No. 6, June, 2019, E-ISSN: 2222-6990 @ 2019 HRMARS

Fahmi, I. (2013). Pengantar Manajemen Keuangan Teori dan Soal Jawab. Bandung: Alfabeta.

Fidyati, N. (2003). Faktor-faktor yang Mempengaruhi Kebijakan Hutang Perusahaan Publik di Indonesia. Jurnal Ekonomi Manajemen dan Akuntansi, Vol. 1, No. 1.

Gill, A. \& Mathur, N. (2011). Factors That Influence Financial Leverage of Canadian Firm. Journal of Applied Finance and Banking, 1 (2), 19-37.

Gitasudarmo, A., \& Basri, I. (2002). Manajemen Keuangan. Yogyakarta: BPFE.

Hanafi, M. M. (2004). Manajemen Keuangan. Edisi 2004/2005.CetakanPertama. Yogyakarta: BPFE.

Halim, A. \& Sarwoko, S. (1995). Manajemen Keuangan. Edisi Pertama. Yogyakarta: AMP YKPN

Horne, V. \& Wachowicz. (2013). Prinsip-prinsip Manajemen Keuangan. Edisi Indonesia. Jakarta: Salemba Empat.

Husnan, S. (2005).Dasar-Dasar Teori Portofolio dan Analisis Sekuritas. Yogyakarta: AMP YKPN.

Husnan, S. \&Pudjiastuti, E. (2012).Dasar-dasar manajemen keuangan edisi keenam. Yogyakarta: UPP STIM YKPN.

Jensen, M. C. \& Meckling, W. H. (1976). Theory of The Firm Managerial Behavior, Agency Cost, and Ownership Structure. Journal of Financial Economics, 6, V.3, No.4,305-360.

Kasmir. (2011). Analisis Laporan Keuangan. Jakarta: PT. Raja Grafindo Persada.

Larasati, E. (2011). Pengaruh Kepemilikan Manajerial, Kepemilikan Institusional dan Kebijakan Dividen terhadap Kebijakan Utang Perusahan. Jurnal Ekonomi Bisnis. 16(2), 103-107.

Munawar, A. (2009). Analisis Pengaruh Aset Tetap, Likuiditas, Ukuran, dan Profitabilitas Terhadap Struktur Kapital Perusahaan. Jurnal Ilmiah Ranggagading. Vol 9(1), 24-33.

Murni, S \&Andriana. (2007). Pengaruh Insider Ownership, Institusional Investor, Dividen Payments, dan Firm Growth terhadap Kebijakan Hutang Perusahaan. Jurnal Akuntansi dan Bisnis.Vol. 7 No.1 Februari 2007,15 -24.

Myers, S. (1984). The Capital Structure Puzzle. Journal of Financial. (39).

Myers. S., \& Majluf. (1984). Corporate Financing and Investment Decision When Firms have information Investors Do Not Have. Journal of Finance Economics. 13, 187-221.

Nurhayati, I. (2004). Kepemilikan Manajerial dan Agency Konflik: Analisis Pengaruh Kepemilikan Manajerial, Pengambilan Resiko, Kebijakan Utang dan Dividen. Tesis. Malang: Universitas Brawijaya.

Padron, Y. G., Apolinario, R. M. C., Santana, O. M., Martel, V. C. M., \& Sales, L. J., (2005).

Determinant Factor of Leverage: An Empirical Analysis of Spanish corporations. The Journal of Risk Finance, Vol. 6, 60-68.

Pearce, John A., \& Richard, B. R. J. (2008). Manajemen Strategi, Formulasi, Implementasi, dan Pengendalian. Penerjemah Yanivi Bachtiar, Christine. Jakarta : Salemba Empat.

Purwasih, D., Restu, A., \& Al Azhar, L. (2014). Analisis Pengaruh kepemilikan Manajerial, Kepemilikan Institusional, Kebijakan Dividen, Profitabilitas, Ukuran Perusahaan, dan Struktur Aset Terhadap Kebijakan Hutang pada Perusahaan Manufaktur Yang Terdaftar di Bursa Efek Indonesia Periode 2010-2012. JOM Fekon Vol.1 No. 2 Oktober 2014.

Putra, Dedi., \& Ramadhani, L. (2017). Analisis Faktor-Faktor yang Mempengaruhi kebijakan Hutang Pada Perusahaan Jasa yang Listing di BEI Tahun 2013-2015. Jurnal Akuntansi \& Keuangan .Vol. 8 No. 1.

Riyanto, B. (2011). Dasar-Dasar Pembelanjaan Perusahaan. Edisi ke 4. Yogyakarta: BPFE Yogyakarta. 
Sarda, S. (2009).Studi Struktur Modal Pada Perusahaan Manufaktur Di Bursa Efek Indonesia Periode Tahun 2005-2008.Jurnal Ekonomi Balance.Vol 5(1), 52-68.

Sari, D. H, Djazuli, A. \& Aisjah, S. (2013). Determinan Struktur Modal dan Dampaknya terhadap Nilai Perusahaan. Jurnal Aplikasi Manajemen. Vol.11 No.1, Maret 2013, 77-84.

Sartono, A. (2010). Manajemen Keuangan Teori dan Aplikasi. Edisi ke4 Yogyakarta: BPFE.

Siregar, D. R. H, \& Wiksuana, I. G. (2015). Pengaruh Pertumbuhan Perusahaan, profitabilitas, Likuiditas, dan Struktur Aktiva terhadap Leverage Keuangan Perusahaan Subsector Textile dan Garment di BEl. E.Jurnal Manajemen Universitas Udayana. Vol.4. No. 9.

Sujoko, \& Ugy, S. (2007). Pengaruh Struktur Kepemilikan Saham, Leverage, Faktor Intern dan Faktor Ekstern terhadap Nilai Perusahaan. Jurnal Manajemen dan Kewirausahaan. 9 (1), 41-48.

Titman, S., \& Wessel, R. (1988). The Determinant of Capital Structure Choice. The Journal of Finance. 43, 1-19.

Wahidahwati. (2002). Pengaruh Kepemilikan Manajerial dan Kepemilikan Institusional pada Kebijakan Hutang Perusahaan: sebuah perspektif Theory Agency. Jurnal Riset Akuntansi Indonesia, Vol. 5. No. 1.

Weston, J. Fred., \& Thomas, E. C. (1999).Manajemen Keuangan. Edisi Kesembilan, Jilid 2. Jakarta: Binarupa Aksara.

Wibowo, A. J., \& Erkaningrum, I. (2002). Studi Keterikatan antara Dividen Payout Ratio, Financial Leverage dan Investasi dalam Pengujian Hipotesis Pecking Order. Jurnal Ekonomi dan Bisnis Indonesia. Vol.17. No. 4, 506-519.

www.idx.co.id

Yeniatie., \& Destiana, N. (2010). Faktor-Faktor yang Mempengaruhi Kebijakan Hutang Perusahaan pada Perusahaan Non Keuangan yang Terdaftar di Bursa Efek Indonesia. Jurnal Bisnis dan Akuntansi.Vol. 12, No. 1, 1-16. 